\title{
Ssciendo
}

Ethics \& Bioethics (in Central Europe), 2019, 9 (1-2), 57-63

DOI:10.2478/ebce-2019-0005

\section{Modernism and nihilism of the Constitution for the Earth}

\author{
Slavomír Lesňák ${ }^{1}$
}

\begin{abstract}
This article uses the post-modern Nietzsche affirmation as a criterion for an analysis of the philosophical concept of the Constitution for the Earth (Šmajs, 2015) and other texts by Josef Šmajs, the principal author of the theory of evolutionary ontology. The author draws the attention of the group of authors of the Constitution for the Earth to the risk of the modernist and nihilist application of evolutionary ontology and proposes that the theory be extended to include new criteria and methods to enable it to be applied in a more acceptable manner. The author places efforts aimed at the biophilic transformation of culture into the value-based and ethical framework of moderate anthropocentrism instead of the ecocentric approach preferred by the creators of evolutionary ontology. The author also underlines the risk of the application of an ecocentric approach through the application of recent analysis of media presentations of those who support and deny climate change in the work entitled Environmental Ethics and Behavioural Change (Franks, Hanscomb \& Johnston, 2018).
\end{abstract}

Keywords: evolutionary ontology, ethics, culture, nihilism

\section{Introduction $^{2}$}

Whereas evolutionary ontology (EO), as a relatively new philosophical concept, has the ambition to be applied in ethics and other social sciences (or in practical life), this concept should be examined from different perspectives and positions. We will base our investigation into the legitimacy of the goals and forms of the evolutionary and ontological prevention of the death of nature, culture and man on two standpoints: the first will be a postmodern standpoint, as we recognise the achievements and benefits of this "type" of thinking in both philosophy and in its application in society; the second standpoint - perspective - will be active Nietzschean nihilism, primarily on the basis of Gilles Deleuze's interpretation, in which both standpoints are interconnected. In our examination of EO we will partly link these viewpoints with the debate on the "freezing" of EO, which took place in Filosofický časopis [Philosophical Journal] in 2013-2015 (Binka, 2013; Šíp, 2014a; 2014b; Šmajs, 2014; Moudr, 2015).

Josef Šmajs, in his article entitled Proč etika nestačí. Kontologickému základu a revitalizaci morálky [Why Ethics is not enough: On the Ontological Basis and Revitalization of Morals] (Šmajs, 2013b), seeks ways of reshaping the findings of evolutionary ontology (EO) into individual morals. According to Šmajs, ethics can do little to help achieve the goal - the transformation of anti-nature culture to biophilic culture, and so he therefore considers other ways of influencing individual morals in a desirable way. ${ }^{3}$ He does this through education and the use of new cultural sciences, as well as by encouraging a change in the legal framework, something he has long been trying to bring about. ${ }^{4}$

\footnotetext{
${ }^{1}$ Masaryk University, Faculty of Education, Department of Civic Education, Brno (Czech Republic); email: lesnak@ped.muni.cz

2 The following text is not an attack on EO, but a critical effort to promote its meaningful and constructive application in ethics, which currently contains several conflicting and controversial elements, to which we will draw attention.

3 Another person who agrees with Šmajs's opinion is Richard St'ahel', which considers environmental ethics as a discipline that is unable to put its own findings into practice. He therefore focuses his attention primarily on political environmental philosophy and examines potential for change through a social contract, although he admits this is legal fiction as the prerequisite for the effectiveness of law. However, is ethical theory not also a prerequisite for effective application in social reality? (Suša \& St'ahel', 2016, pp. 163-186).

${ }^{4}$ See, for example, the texts Nájemní smlouva se Zemí [Lease Agreement with the Earth] (Šmajs, 2009), Deklarace závislosti [Declaration of Dependence] (Šmajs, 2012), or Ústava Zeme [Constitution for the Earth] (Šmajs, 2015).
} 
The requirements of Šmajs which are most worth exploring in ethical terms are: $a$. Raising nature up to the status of an entity, even the most supreme entity (or making the Earth sacred) $;^{5}$ $b$. Deriving moral and ethical arguments from ontologically learned EO theory; ${ }^{6} c$. Substitution of one spiritual paradigm for another - as a means of influencing individual morals - in a roundabout way. ${ }^{7}$

Although the first requirement is the most radical of all, we are afraid that all three are not only "dangerous in postmodern terms", but can also lead to nihilism, which does not benefit any biophilic concept. We will be returning to these requirements later in the text, in order to verify their (varying degrees of) danger and possible nihilism.

\section{The story of the master and the slave in the context of affirmation}

In his work Nietzsche and Philosophy (originally dating from 1962), Deleuze interprets the story of the master and the slave in Nietzschean terms: the slave can overcome the master only by defining himself to him, and construes himself on the basis of that definition (Deleuze, 2016, pp. 193-213). In his analysis of this text, Tomáš Hauer notices Deleuze's emphasis on the authentic definition of oneself and even considers it to be one of the attributes of postmodern thinking (Hauer, 2014). Since the master does not need to define himself to others, he thinks, acts and lives as it suits him, unlike the subjugated. The slave, on the other hand, is defined primarily by another - by the master, not by himself. As he lacks the power to affirm himself, he has to negate the master, the other. In this view the slave is a weakling, who is unable to create his own values or take a free view of life.

In this light, each creation of values and norms derived from someone else seems inauthentic and alienated - incorrect. It is also incorrect to derive values from systems of thought; this is a weakness that leads to individual and social nihilism. This does not just mean a state of aimlessness in an individual or even a move towards nothingness, but nihilism as a psychological $^{8}$ state, in which man is subconsciously controlled by reactive forces, when a person falls into a passive state (Nietzsche, 1992, p. 635).

An important element in nihilism perceived in this way is thus the lack of affirmation, which we see as self-realization, self-confirmation. It is part of the individual sense of happiness that man achieves when engaged in unbridled self-realization. We are of the opinion that environmental ethics should always include such an individualistic eudaimonist dimension, so as not to slip into "merely" protection of the environment, nature, the human species, or culture. We assume that the founder of EO, Šmajs, sees this significant individualistic dimension in a similar light, as he writes, for example, about the meaningless and unnatural work that people do in the modern technical age (Šmajs \& Buchtová, 2013). Later in the text Nietzschean affirmation serves partly as a means of achieving the individual dimension of ethics, and partly

\footnotetext{
5 "Ethical rationality, which traditionally dealt only with the moral relationships between people and other elements of society, must come to terms with the fact that the supreme moral entity becomes unjustly theoretically deadened nature" (Šmajs, 2013b, p. 807). With regard to the sacredness of the Earth Šmajs again writes: "in other words, how to use evolutionary ontology, art, and new cultural sciences to make the Earth sacred again...” (Šmajs, 2013b, p. 811).

6 "How can important moral regulations ... be derived directly from ethical arguments ... so that the new morals precede reality ... to enable them to emerge from general ontologically learned theory" (Šmajs, 2013b, p. 807).

7 "It seems that we must proceed from the evolutionary ontology of culture to the new morality in a roundabout way through the deliberate change of the spiritual paradigm, through the change in the rules for the creation of culture as an artificial system that is existentially subordinate to the biosphere. Evidently it is only in the process of the physical transformation of anti-nature culture into a biophilic culture that people can take a new attitude to the world, a new pro-nature morality" (Šmajs, 2013b, p. 812).

8 "Nihilism as a psychological state ... emerges if a man has postulated integrity, systematicity, even organisation in all events" (Nietzsche, 1992, p. 635).
} 
as a means of preventing the rejection of totalitarian ideological structures, the absence of which again is a symptom of nihilism.

\section{Contemporary nihilist elements of society}

Elements of the nihilism described above can also be seen in contemporary society: a. An imaginary moral entity is daily employed in a program of extraneous objectives (which do not have to be in any way meaningful) - in Frommian terms - that entity's self-realization is low, deprived of activity; taking power over one's own life may occur in the form of ignoring, rejecting or sabotaging meaningless work activities, orders, motivational events, etc.;

b. From the viewpoint of the reflection of anti-nature culture and life - the moral entity is aware of this character, but is unable to overcome this prevailing paradigm, so becomes reconciled and resigned to a day-to-day anti-biophilic system;

c. A moral entity has become or is in the process of becoming an object of technology (Jonas, 1985);

d. The last element is when a moral entity is affected by the forces of bodily and spiritual hedonism - consumerism, entertainment and experience instead of self-realization and affirmation.

\section{Problematic application of EO in the Constitution for the Earth}

The challenge of the philosophical concept of the Constitution for the Earth is intended to be ratified by individual states - this assumes the existence of biophilic parliamentary ${ }^{9}$ majorities and electoral majorities. The main dilemma voters face before "donning biophilic attire" will be the question of whether the protection of nature and culture will be enough of a reason for a change of life, if it is not just present comfort that is at stake, but if there is also the risk of political instability and a consequent threat to life.

Moral entities should consider recognising the values that are outside of them - the Earth as an entity, accept the value of culture as such and its potential for continuation, then acknowledge the limits on the value of well-being and self-realization anti-nature activities.

Individual moral choice for biophilic culture therefore does not have to mean a major shift away from the elements of contemporary nihilism: the individual is expected to exchange his or her faith in the positive elements of contemporary spiritual culture (e.g. science which will eventually save us from disaster) for faith in the new biophilic ${ }^{10}$ spiritual framework of culture (e.g. science which will eventually save our well-being).

And what is meant by setting nature as the supreme moral entity? That nature has the exclusive right to make decisions about itself, ${ }^{11}$ or that it is a higher entity creating moral standards as a person (in the man - nature relationship)? Does the ontological, systemic superiority of nature have anything in common with moral superiority?

It is known that deriving the right action from ontology after postmodern is somewhat out of fashion - "The tree and root inspire a sad image of thought that is forever imitating the multiple on the basis of a cantered or segmented higher unity", write Deleuze and Guattari in their book A Thousand Plateaus (Deleuze \& Guattari, 2010, p. 24). On the other hand, we might say that the ecological crisis is a fact that shows humanity and the planet that "they are in one and the same boat", meaning that the boat needs to be looked after. It is therefore evident that

\footnotetext{
${ }^{9}$ Due to time constraints we will not be discussing all possible types of accession to international treaties; we will be using ratification by Parliament to cover all forms.

${ }^{10}$ The term "biophilic culture" is in itself an oxymoron, being a utopia of life that does not destroy other life.

${ }^{11}$ Constitution for the Earth: "Aware of our responsibilities to future generations we declare the Earth to have a unique ontological creativity and subjectivity - with a value higher than man or culture. We consider the natural creativity of the Earth, which gave life to man and has enabled culture and human rights, to be superior to human creativity and the rights of people" (Šmajs, 2015, p. 6).
} 
the postmodern refusal to draw conclusions from ontology has its limits, while on the other hand - favouring a living person over protecting inanimate ideas has no such limits, since "metaphysical categories... care as much about life as an SS officer's boot" (Bělohradský, 1997, p. 10)

However, EO does not want to protect nature and culture because they are "categories", but because they have value in themselves, are unique, and, moreover, nature is a living "organism". What is more important is the question of placing them above human life: should the life of a particular person be forfeited in the event of a conflict? An individual human life is unique and never to be repeated; the evolution of nature, however, will continue without humans. It therefore seems that the supreme moral entity should not be nature, and should remain man himself: the EO eco-centrism therefore does not seem to be a suitable ethical concept, even if it is systemically supported.

The principle of favouring the value of nature over the value of an individual person's life would lead to the real non-existence of that person (and whole groups of people) and to a nonexistence of values - devaluation of the value of an individual's life (compared to nature as the supreme moral entity) and thus to nothingness as a value basis. As Deleuze writes: "life acquires the value of nothingness to the extent to which it is denied and denigrated. Denigration always assumes fiction: denigration and distortion occur through fiction; it is through fiction that something opposes life. Life as a whole thus becomes unreal, is represented as a dream, it acquires in its totality the value of nothingness" (Deleuze, 2016, p. 255). Is the acceptance of the idea of a biophilic culture by convinced individuals such a fiction, one which separates them from the real world of themselves and from the value of other people's lives?

However, nowadays the denigration of life on the basis of fiction is not only promoted by advocates of biophilic culture, just the opposite in fact: it is common to deny and denigrate the lives of people suffering from an ecological crisis due to the continuation of prosperity, or due to faith in the idea of a self-operating market (this denigration is also directed at one's own life). However, what principal meaning would there be in the exchange of one type of denigration of life (on the basis of contemporary fiction) for the denigration of life on the basis of the fiction of biophilic culture?

So, if Šmajs's "nature as the supreme moral entity" (Šmajs, 2013, p. 807) means in practice recognising action that does not disrupt the evolution of nature as being correct, with regard to the above we propose adding that and also, what is more correct is action that not only does not disrupt the evolution of nature, but also does not threaten or degrade the life of any particular person.

\section{Change of morality conditional "in a roundabout way"}

"For a society which has no inner guards, all the police in the world are not enough to make it a civic society," stated an American philosopher of Slovak origin in his talk entitled Awakening from Nihilism (Novak, 1994, p. 9). Also, in order to change constitutions and laws, EO will need biophilic-oriented citizens literate in ontology to enforce that change: "as a highly technologically advanced civilization we paradoxically need education to help people understand the absolute priority of life", writes Šmajs (Šmajs, 2008, p. 244).

The incorporation of the evolutionary-ontological view of the world into education (the division of the world into constantly evolving nature and culture, their interconnectedness, the dependence of culture on nature, the integration of another view of science and every human activity) could not only lead to greater plurality, but would also fulfil what has now become a very chaotic and unsystematic view of nature and culture. In an ideal case scenario, including EO in the syllabus would gradually incite enthusiasm for evolutionary ontology in pupils, 
students and even in voters, giving them a better eco-system vision of the world. ${ }^{12}$ However, there would be no need to follow up on the controversial proposals contained in Constitution for the Earth: "We pledge to protect the Earth from the selfish expansion of predatory culture. We intend to promote its value, claims and rights, which are superior to those of man and nature, by all means possible" (Šmajs, 2015, p. 6).

While we do not consider ontological education to be "roundabout", but instead as the functional enrichment of our view of the world, the conjunction "all means" in the constitution are. The conjunction in itself involves the undemocratic seizure of power on the planet, violence, manipulation, the principle of leadership, terrorism, etc. The use of "all means" for the higher interest, so typical for modernist ${ }^{13}$ projects are a step back for EO (or for the application of EO). The text in the constitution is reminiscent of how supporters of EO are seen as the "vanguard" of biophilic culture, which, by establishing it, change the conditions for other people to enable their old anti-nature morality to "die" and allow them to finally adopt a new, evolutionary-ontological morality with new conditions. It is also hard to imagine that nonbiophilic "all means" could lead to a biophilic culture ${ }^{14}$ rather, history shows they are directed towards a practical and value nothingness. ${ }^{15}$

We assume that the non-anthropocentric application of EO "in a roundabout way" in Constitution for the Earth is used due to the lack of the value of man at its centre, which is already occupied by other, "higher" values. In fact, this incriminated text of Constitution for the Earth shows that it makes sense to revise EO from the perspective of postmodern philosophy and ethics; otherwise, instead of avoiding nihilism EO directs itself towards it.

In the discussion concerning the "freezing" of evolutionary ontology this view shows that ethics is not merely an unnecessary "extension" of EO. We believe that this "reverse" is possible for EO due to the fact that the evolutionary-ontological picture also contains contradictory ontic elements such as man and his product - culture. ${ }^{16}$

\section{The "threat" of change based on the application of EO?}

The application of EO to action as outlined above may lead to what in the introduction to our article we called the nihilistic paralysis of a moral entity. That paralysis is also explored by the authors of Environmental Ethics and Behavioural Change (Franks, Hanscomb \& Johnston, 2018). The barriers that the authors see to people's environmental behaviour are uncertainty over the evidence of climate change (the problem of denial, ${ }^{17}$ the complexity of the

\footnotetext{
${ }^{12}$ Do we belief in miracles? Konrad P. Liessmann writes about education as a new religion (Liessmann, 2018).

${ }^{13}$ Radim Šíp drew attention to the modernism of certain EO ideas: "The strong anthropocentrism that lay behind the Promethean myth of the bearer of Truth, and which evolutionary ontology inherited from early modern thinking, may be exchanged by Professor Šmajs for a far more balanced position. For a position of weak anthropocentrism - anthropocentrism which, although it acknowledges its roots, place and origin in culture, can on the other hand work far more boldly and creatively with meanings and values that extend beyond previous findings and ways of thinking. This type of anthropocentrism does not make the mistake made by all those who consider themselves to be non-anthropocentric, biocentric, zoocentric or ecocentric" (Šíp, 2014a, p. 441).

14 "All means" would mean the worst mostly for women. Wendy Lynne Lee writes about the consequences of radical ecocentrism in her book Eco-Nihilism. The philosophical geopolitics of the climate change apocalypse (Lee, 2017, pp. 31-36).

${ }^{15}$ Which does not mean that such a text and the tools it calls for cannot become a terrifying reality at a time of ecological disaster.

${ }^{16}$ We see no problem in the claim that ethical contexts as part of the "artificial" and the description of that world could also correct the actual evolutionary-ontological concept. This may cause a shift from the "freeze" of evolutionary ontology "without attributes" to ontology linked to other social sciences.

${ }^{17}$ TV debates tend to take on a dual form, where most of the scientists supporting evidence of climate change hold an equal position to those who deny it. In addition to disproportion, the absence of (meaningful) conclusions to the discussion is also a mistake, inciting the public to "flee" from such an unpleasant topic (Franks, Hanscomb \& Johnston, 2018, p. 114).
} 
information ${ }^{18}$ ), the evil nature ${ }^{19}$ of the change, failure to effectively respond to known dangers (habit), existing habits, values and desires, psychological denial (Franks, Hanscomb \& Johnston, 2018, pp. 114-144).

From this perspective we might also see the roundabout approach in Constitution for the Earth as the horrific nature of the change - not only do ecological crisis and disaster sound terrible in themselves, but also the changes proposed by EO seem risky, which may be the reason for hesitation on the part of moral entities. This is another reason why we do not see the evolutionary-ontological background in the perception of correct action to be a determinant of correct action, but as a context that gives the EO school of ethics an advantage over other ecological concepts.

\section{References}

BINKA, B. (2013): Pokus o novou interpretaci jedné "záslužné" teorie aneb nezaslouženě zamrzající evoluční ontologie [Attempt to re-interpret one "meritorious" theory or the undeserved freezing of evolutionary ontology]. In: Filosofický časopis, 61(6), pp. 827-843.

BĚLOHRADSKÝ, V. (1997): Mezi světy a mezisvěty [Between worlds and interworlds]. Prague: Votobia.

DELEUZE, G. (2016): Nietzsche and philosophy. Prague: Herrmann \& synové.

DELEUZE, G. \& GUATTARI, F. (2010): A Thousand plateaus. Prague: Herrmann \& synové. FRANKS, B., HANSCOMB, S. \& JOHNSTON, S. F. (2018): Environmental ethics and behavioural change. London \& New York: Routledge.

HAUER, T. (2014): Skrze postmoderni teorie [Through postmodern theory]. Prague: Karolinum.

JONAS, H. (1985): The Imperative of Responsibility: In Search of an Ethics for the Technological Age. Chicago: University of Chicago Press.

LEE, W. L. (2017). Eco-Nihilism: The Philosophical Geopolitics of the Climate Change Apocalypse. Lanham: Lexington Books.

LIESSMANN, K. P. (2018): Vzdělání jako provokace [Education as provocation]. Prague: Academia.

MOUDR, V. (2015): "Zamrzlá" interpretace evoluční ontologie? ["Frozen” interpretation of evolutionary ontology?]. In: Filosofický časopis, 63(4), pp. 581-593.

NIETZSCHE, F. (1992): Fragments of nihilism. In: Filosofický časopis, 40(2), pp. 626-637.

NOVAK, M. (1994): Probuzení z nihilismu. V prípravě na 21. století: čtyři lekce ze století dvacátého [Awakening from nihilism. In preparation for the 21st Century: Four lessons from the twentieth century]. Prague: Civic Institute.

SUŠA, O. \& SŤAHEL, R. (2016): Environmentálni devastace a sociálni destrukce [Environmental devastation and social destruction]. Prague: Filosofia.

ŠÍP, R. (2014a): Jak oživit "zamrzlou" evoluční ontologii [How to revive "frozen" evolutionary ontology]. In: Filosofický ćasopis, 62(3), pp. 431-442.

ŠÍP, R. (2014b): Proč raná moderna [Why early modernity]. In: Filosofický časopis, 62(6), pp. 939-945.

\footnotetext{
${ }^{18}$ While postmodern authors reject simple truths, the directness of knowledge, certainty and truth, the social psychologist $\mathrm{O}$. Payne sees the human mind as preferring situations that are simple, local, immediate and direct. However, the nature of climate change is precisely the opposite, which complicates its acceptance by the public (Franks, Hanscomb \& Johnston, 2018, p. 117).

${ }^{19}$ According to the authors of the work the incredible nature of information about climate change goes as far as seeming to be sci-fi, leading people to see climate change as a conspiracy, a plot hatched by scientists.
} 
ŠMAJS, J. (2008): Filosofie - obrat k Zemi. Evolučně ontologická reflexe přirody, kultury, techniky a lidského poznání [Philosophy - turning to Earth: The evolutionary ontological reflection of nature, culture, technology and human knowledge]. Prague: Academia.

ŠMAJS, J. (2009): Nájemní smlouva se Zemí [A lease with planet Earth]. In: Životné prostredie, 39(1), p. 47.

ŠMAJS, J. (2012): Deklarace závislosti [Declaration of dependence]. In Filosofický časopis, 60(2), pp. 313-316.

ŠMAJS, J. (2013a): K problému oživení "zamrzlé" evolučné ontologie [On the problem of reviving "frozen" evolutionary ontology]. In: Filosofický časopis, 62(5), pp. 759-764.

ŠMAJS, J. (2013b): Proč etika nestačí. K ontologickému základu a revitalizaci morálky [Why ethics is not enough: The ontological basis and revitalization of morality]. In: Filosofický časopis, 61(6), pp. 803-826.

ŠMAJS, J. (2015): Ústava Země [Constitution of Earth]. Banská Bystrica: PRO.

ŠMAJSOVÁ BUCHTOVÁ, B., ŠMAJS, J. \& BOLELOUCKÝ, Z. (2013): Nezaměstnanost [Unemployment]. Prague: Grada Publishing. 